\title{
Współczesny przedsiębiorca
}

Kim na współczesnym rynku jest przedsiębiorca? Jakimi cechami powinien się charakteryzować? Przedsiębiorca powinien łączyć funkcje:

1. założyciela-organizatora,

2. kierującego-zarządzającego,

3. ponoszącego odpowiedzialność społeczną, finansową i prawną za swoją działalność.

Jeżeli przyjmie się takie założenia, to można stwierdzić, że nie jest przedsiębiorcą ani zawodowy menedżer zatrudniony do prowadzenia firmy, ani właściciel przedsięwzięcia, ponieważ nie spełnia drugiego z wymienionych warunków. Nie można też nazwać przedsiębiorcą kogoś, kto nie ponosi ryzyka, gdyż w dzisiejszych czasach nie ma przedsiębiorczości, która byłaby od niego wolna. Obecne realia gospodarcze sąznacznie bardziej wymagające od tych, które panowały na początku lat 90 . XX w. i które umożliwiły dynamiczny wzrost liczby przedsiębiorstw w różnych dziedzinach produkcji i usług, co przełożyło się na niespotykany w Polsce i w innych państwach dawnego bloku wschodniego wzrost gospodarczy. Ale wtedy wachlarz cech niezbędnych przedsiębiorcy, w porównaniu z dzisiejszymi wymaganiami, był takim (posłużmy się określeniami zaczerpniętymi z motoryzacji),,standardem” - ,tańszą wersją”. Aby obecnie zaistnieć na rynku gospodarczym, potrzeba ,,szeregu dodatków” zapewniających „komfort jazdy”- czyli atrybutów mogących zapewnić powodzenie.

Zadaniem nauczycieli przedmiotu ,podstawy przedsiębiorczości” jest wskazanie uczniom tego, co jest ważne dla przedsiębiorcy, co i jak robić, aby to osiagnąć, żeby w niedalekiej przyszłości kształtować rzeczywistość życia gospodarczego w Polsce. Oczywiście, jak w każdej dziedzinie i w każdym środowisku, ludzie są mniej lub bardziej chętni do akceptowania i przyswajania rzeczy nowych i często wymagających dużego wysiłku. Niektórych uczniów można oceniać jako przedsiębiorczych, inni tacy nigdy nie będą. Ktoś mógłby powiedzieć, że bez tego przedmiotu tak by się stało, ale dzięki niemu podejmowanie przez uczniów pewnych działań w przyszłości będzie może nie oczywiste, ale jednak łatwiejsze, bo częściowo już poznane.

Współczesny przedsiębiorca to człowiek łączący w sobie cechy organizatora, menedżera i przywódcy. Takie są wymagania teraźniejsze, ale przyszłość może je zwiększyć.

Do cech, które można uznać za niezbędne u współczesnego przedsiębiorcy, pogrupowanych w zależności od trzech funkcji wymienionych wyżej, można zaliczyć:

\section{Cechy związane z organizowaniem.}

- „Duch przedsiębiorczości”, potrzeba działania (tworzenia) - przedsiębiorca to człowiek, w którym wyzwala się ,duch przedsiębiorczości”, potrzebujący konkretnego działania. Rozwój gospodarczy zależy od ducha przedsiębiorczości wyzwalającego boom gospodarczy (Schumpeter 1960). W razie kryzysu liczy się szybkość dostosowania się do nowych wymagań, które inni będą powielać, naśladować.

- Kreatywność - zdolność tworzenia czegoś nowego, oryginalnego, twórczego. Realizowany pomysł jest nowością na rynku, jest odmienny od wykorzystywanych przez innych 
przedsiębiorców. Należy jednak pamiętać, że efektywna strategia produktu musi zręcznie łączyć wprowadzanie nowych produktów z istnieniem dawnych, aby przedsiębiorstwo mogło najlepiej spożytkować swoje szczególne zasoby (Kramer 2000).

- Optymizm - wiara w powodzenie swojego przedsięwzięcia, dostrzeganie jego pozytywnych stron.

2. Cechy menedżerskie, powiązane bezpośrednio z zarządzaniem. Jest to chyba najważniejsza grupa cech, decydująca o przetrwaniu i rozwoju, teraźniejszości i przyszłości przedsiębiorstwa, o powodzeniu całego przedsięwzięcia.

- Zarządzanie zasobami ludzkimi - współczesny przedsiębiorca stawia ludzi na pierwszym miejscu, szanuje ich i ufa im, potrafi zaakceptować ich słabości, sprawia, że dobrowolnie mu się podporządkowują, podejmują decyzje, które on tylko koordynuje. $Z$ tej cechy wypływają umiejętności niezbędne w zarządzaniu: przewodzenie i motywowanie. Motywowanie do strategii, aby być najsilniejszym z potężnych (Drucker 2004).

- Zarządzanie czasem - osoba decydująca się zostać przedsiębiorcą musi sobie zdać sprawę, że jest się nim przez 24 godziny na dobę, 7 dni w tygodniu. Czas jest zasobem, ale - w przeciwieństwie do wielu innych zasobów - nie można go kupić ani zmagazynować, dlatego przedsiębiorca musi go umieć jak najlepiej wykorzystać.

- Wizjonerstwo - współczesny przedsiębiorca powinien mieć umiejętność wyobrażenia sobie swoich planów, zamierzeń, co jeszcze wzmaga chęć osiągnięcia wyznaczonych celów.

- Uporczywe dążenie w wybranym kierunku - ale warto zaznaczyć, choć brzmi to nieco przewrotnie, że powinno ono być elastyczne. Nie może się odbywać za wszelką cenę. Zdarzają się sytuacje, kiedy pewnych działań należy zaniechać albo zmienić ich kierunek lub natężenie. Czasem upór może doprowadzić do nieodwracalnych szkód w przedsiębiorstwie lub w jego szeroko pojętym otoczeniu, co może się ujemnie odbić na samym przedsiębiorcy. Należy stosować strategię polegającą na formułowaniu zbioru długofalowych celów przedsiębiorstwa i ich modyfikacji, w zależności od zmian zachodzących w otoczeniu, określaniu zasobów i środków niezbędnych do osiagnięcia tych celów oraz sposobów postępowania zapewniających optymalne ich rozmieszczenie i wykorzystanie, aby było możliwe elastyczne reagowanie na wyzwania rynku i zapewnienie przedsiębiorstwu warunków egzystencji i rozwoju (Penc 1994).

- Umiejętność wykorzystania informacji - bardzo ważna cecha, zważywszy na zalewające nas ze wszystkich stron informacje. Człowiek przedsiębiorczy to osoba, która w natłoku informacji potrafi wypatrzyć przysłowiową ,czterolistną koniczynę”, umie ją zanalizować, przetworzyć i z korzyścią zastosować w swoim przedsiębiorstwie. Przyjmuje się przy tym ogólne założenie, że informacja nie ma ceny zerowej, w związku z czym obowiązuje rygor oszczędnego gospodarowania jej zasobami (Kramer 2000).

- Myślenie systemowe - zdolność wykorzystania wiedzy z różnych dziedzin oraz umiejętność wiązania pewnych zjawisk i informacji w celu ich zastosowania w swojej działalności.

- Innowacja, czasami „myślenie na opak” - podejmowanie w pewnych sytuacjach decyzji wbrew przyjętym regułom. Przyszłość należy do ludzi wychodzących poza schematy. Podstawą przedsiębiorczości jest zmysł innowacyjny (Drucker 1991).

- Etyka - mimo że umieszczona na końcu listy, jest bardzo ważna we współczesnym biznesie. Nie można jej kupić ani sprzedać, ale należy do aktywów przedsiębiorstwa. To, czy przedsiębiorca się nią kieruje, czy też nie, wpływa pośrednio na wyniki finansowe firmy. W Europie Zachodniej w niektórych kręgach biznesu panuje opinia, że jeżeli przedsiębiorca nie kieruje się ogólnie przyjętymi regułami moralnymi, jest głupcem i przegrał walkę przed jej podjęciem. Nieetyczne postępowanie w gospodarce rynkowej to krótkowzroczność, która prędzej czy później kończy się porażką zawodową, a czasem i osobistą przedsiębiorcy. 
Tych cech - atrybutów menedżera - można wymienić więcej, np. dynamizm czy zdecydowanie. Poza tym trzeba wspomnieć o zasobie wiedzy fachowej. Menedżer powinien dysponować wiedzą o prawach i mechanizmach gospodarki rynkowej, o kształtowaniu się rynku nabywcy, praktycznym zastosowaniu i realizacji strategii marketingowych.

\section{Cechy związane z ponoszeniem ryzyka.}

- Odpowiedzialność - przedsiębiorstwo funkcjonuje w określonym otoczeniu i nieodpowiedzialne decyzje (szczególnie jeżeli dotyczą przedsiębiorstw dużych) mogą prowadzić do problemów społecznych, a także wpływać negatywnie na wizerunek przedsiębiorstwa. Może to doprowadzić do osłabienia jego pozycji na rynku, a nawet do upadłości.

- Ryzyko finansowe - niewłaściwe decyzje (inwestycje) finansowe mogą doprowadzić do utraty płynności finansowej, a także do upadłości przedsiębiorstwa. Konieczne jest porównanie kosztów ryzyka z korzyściami, które można odnieść, podejmując je (Cohen 1998).

- Ryzyko prawne-ściśle powiązane ze wspomnianymi wcześniej. Nieodpowiedzialne i niewłaściwe decyzje (głównie finansowe) mają często finał w sądzie.

Jak widać, ta ostatnia grupa cech to zagrożenia czyhające na współczesnego przedsiębiorcę. Jeżeli jednak ma on atrybuty wymienione w pkt. 1 i 2 i potrafi je wykorzystać, to poradzi sobie z przeciwnościami.

Podsumowując - wydaje się, że najważniejsze nie jest przekazanie młodym ludziom jak największej ilości wiedzy podręcznikowej, lecz wskazanie im, jak zdobywać ważne umiejętności i kształtować cechy niezbędne współczesnemu przedsiębiorcy. Istotne jest również to, aby tematy i zagadnienia kształtujące przedsiębiorczość u młodych ludzi wprowadzać już we wczesnych etapach nauki.

\section{Literatura}

1. Cohen G.N.,1998, Biznesplan doskonaty, Business Press, Warszawa

2. Drucker P.F., 1991, Innowacja i przedsiębiorczość. Praktyka i zasady, PWE, Warszawa

3. Drucker P.F., 2004, Natchnienie i fart, czyli innowacja i przedsiębiorczość, Studio Emka, Warszawa

4. Kramer T., 2000, Podstawy marketingu, Polskie Towarzystwo Ekonomiczne, Warszawa

5. Penc J., 1994, Strategie zarzadzania, Agencja Wydawnicza „Placet”, Warszawa

6. Schumpeter J., 1960, Teoria rozwoju gospodarczego, PWN, Warszawa

\section{An Entrepreneur for Modern Times}

This paper tries to show an image and define qualities vital to a modern entrepreneur. The requirements for entrepreneurs are very high. An entrepreneur must be both a founder and organizer, as well as manager and leader. In order to play these roles well one should possess certain qualities and abilities. It is necessary to have so called "spirit of enterprising", to be creative and innovative, which will let us find a niche on the market and prosper in the competitive world. Furthermore, it is vital to be able to manage the personnel and time - an important resource in our times. Also, we should be able to interpret and use the accessible information and our knowledge that should be constantly broadened. It is important to have the sense of responsibility, as there is no enterprise without financial and legal risk.

Above list shows that this set of qualities and abilities is hard to develop. The teachers' task, who give Introduction to Enterprising lesson, is to show young people what qualities are necessary for a modern entrepreneur, and what to do in order to develop them. Today's students should decide on the shape of tomorrow economy in Poland. 